\title{
W kierunku ilościowej teorii wzrostu złożoności świata
}

\section{Wstęp}

Badanie wzrastającej z biegiem czasu złożoności świata - która już dawno przestała być traktowana po prostu jako jego trzeciorzędna, przygodna właściwość ${ }^{1}$ - jest jednym z zadań współczesnej filozofii przyrody. Zainteresowanie tym tematem szczególnie pobudza umacniająca się z biegiem czasu wiedza, że wszystkie przedmioty i procesy fizyczne są ze soba genetycznie spokrewnione i że wszystkie powstały na którymś etapie rozwoju Wszechświata z innych układów ${ }^{2}$. Wyłania się więc pytanie o przebieg i „mechanikę" tego uniwersalnego procesu, w wyniku którego z izotropowej mieszaniny cząstek elementarnych powstał ostatecznie świat, jaki znamy: świat atomów i związków chemicznych, galaktyk i gwiazd,

${ }^{1}$ Zwróćmy choćby uwagę, jak bliskie popularnemu dziś myśleniu o wzrastającej z czasem złożoności świata jako o jego fundamentalnej, nieredukowalnej własności, i jak przez to „nowoczesne”, są choćby systemy filozoficzne H. Bergsona i P. Teilharda de Chardin, pochodzące wszak sprzed ok. stu lat.

2 Najważniejszymi krokami na drodze do uznania historycznej wspólnoty wszystkich przedmiotów i procesów fizycznych były m.in.: uznanie wspólnego chemicznego źródła materii nieożywionej i ożywionej w I połowie XIX wieku, wspólnego pochodzenia życia na Ziemi oraz jedności atomowej budowy świata materialnego w II połowie XIX wieku i odkrycie globalnej ekspansji Wszechświata w latach 20. XX wieku. 
minerałów, skał i planet, oceanów i pustyń oraz, last but not least, istot żywych, w tym nas, ludzi. Katalog problemów filozoficznych związanych z tak nakreślonym obszarem badawczym jest spory; warto wymienić kilka przykładów.

Badacze redukcji teoretycznej są żywo zainteresowani przebiegiem procesów naturalnych, opisywanych przez teorie redukowane i redukujace ${ }^{3}$ : przykładowo, redukcja teoretyczna biologii do chemii to zagadnienie automatycznie prowokujace do rozważania kwestii abiogenezy. Metafizycy poruszający się w kręgu teorii poziomów rzeczywistości (np. teorii metafizycznej N. Hartmanna ${ }^{4}$ ) posługują się pojęciami typu „emergencji międzypoziomowej” - pojęciami, których egzemplifikacją są przypadki dramatycznego wzrostu złożoności świata, np. wspominane przejście od organizacji abiotycznej do organicznej, uznawane przez Hartmanna za jedno z fundamentalnych ontologicznych „cięć” (Einschnitte). Istnieja ponadto współcześnie wyspecjalizowane programy badawcze skupione na zagadnieniu wzrostu złożoności świata, czasem określane zbiorczym mianem „teorii złożoności” (complexity theory). Badacze ci posługują się najczęściej pojęciami zapożyczonymi z termodynamiki $^{5}$, teorii układów dynamicznych ${ }^{6}$ lub teorii informacji i informatyki ${ }^{7}$, poszukując ogólnego „przepisu na samoorganizację”, który miałby satysfakcjonująco opisywać ewolucję naszego Wszechświata. W tym kontekście współcześnie zwykle przywołuje się pojęcie

${ }^{3}$ W.C. Wimsatt, S. Sarkar, „Reductionism”, [w:] S. Sarkar, J. Pfeifer, The Philosophy of Science. An Encyclopedia, Routledge, Nowy Jork - Londyn 2006, ss. 696-702.

4 N. Hartmann, Nowe drogi ontologii, przeł. L. Kopciuch i A. Mordka, Rolewski, Toruń 1998.

${ }^{5}$ I. Prigogine, Thermodynamics of Irreversible Processes, Wiley, New York 1961.

${ }^{6}$ S. Kauffman, Origins of Order, Oxford University Press, Oxford 1993.

${ }^{7}$ S. Wolfram, A New Kind of Science, Wolfram Media, Champaign IL 2002. 
„emergencji”, zapożyczone z XX-wiecznej tradycji emergentyzmu brytyjskiego $^{8}$.

\section{Problem badawczy i związane z nim kwestie metodologiczne}

Przy badaniu tego typu zagadnień pojawia się palący problem precyzyjnego określenia, które konkretnie spośród wielu przemian zachodzących we Wszechświecie zasługują na naszą uwagę, jako przykłady „emergencji” czy tė̇ wyłaniania się nowej „,warstwy ontologicznej”’? Najczęściej stosowaną metodą jest wybór określonego przypadku i analiza problemu na jego przykładzie; często analizuje się w takich wypadkach proste przykłady termodynamiczne, wyraziste przykłady biologiczne albo modelowe układy informatyczne $^{9}$. Klasę samą w sobie stanowią dwa przykłady dla filozofa „oczywiste”, tj. narodziny życia z materii nieożywionej oraz narodziny istot świadomych z istot nieświadomych - obydwa tak dramatyczne, że do dziś rutynowo podawane jako klasyczne przykłady „emergencji” lub innego typu metafizycznej „sytuacji granicznej”" Taką metodą nie da się jednak odpowiedzieć na najbardziej ogólne pytanie o przebieg historycznego rozwoju złożoności świata - badanie wybranego casusu jako przykładu „nadbudowywania warstwy ontologicznej” lub reprezentanta klasy „procesów emergentnych” z góry już zakłada, że historyczny rozwój złożoności świata przebiega w sposób, który uzasadnia używanie tego typu pojęć. Wydaje się, że przebieg wzrostu złożoności świata jest problemem ogólniejszym od koncepcji „poziomów rzeczywistości” lub emergentyzmu

8 C. L. Morgan, Emergent Evolution, Williams \& Norgate, Londyn 1923; S. Alexander, Space, Time and Deity. The Gifford Lectures at Glasgow 19161918, Macmillan and Co., Londyn 1927.

9 Zob. np. S. Wolfram, dz. cyt.

10 Zob. np. J. Garson, „Emergence”, [w:] S. Sarkar, J. Pfeifer, The Philosophy of Science. An Encyclopedia, Routledge, Nowy Jork - Londyn 2006, ss. 230235. 
jako takiego, które stanowią tylko szczególnego typu odpowiedzi na ów problem.

Istnieje tylko jedna systematyczna droga prowadzaca do faktycznego rozwiązania wyżej zarysowanych problemów - analiza Wszechświata w całym bogactwie występujących w nim form i procesów naturalnych, w porządku historycznym. Dokładnie w ten sposób bada się inne procesy historyczne - np. proces rozwoju życia na Ziemi albo historię ludzkich społeczeństw - aby odpowiedzieć na pytania dotyczące zasadniczych cech ich przebiegu. Nie da się odpowiedzieć na pytanie, czy ewolucja biologiczna przebiega jednostajnie, czy skokowo, nie zbadawszy uprzednio wszystkich dostępnych nam faktów paleontologicznych i genetycznych. Podobnie, nie da się odpowiedzieć na pytanie, jak (i czy) przebiega „nadbudowywanie warstw” lub „emergencja” zjawisk fizycznych, nie zbadawszy uprzednio wszystkich dostępnych nam faktów kosmologicznych i fizycznych. Analiza der Aufbau der realen Welt z samej swojej natury zakłada analizę naszej wiedzy na temat die reale Welt.

Wbrew narzucającemu się przeświadczeniu, że tak zarysowany program badawczy („zbadać cały świat”) jest absurdalnie szeroki, w niniejszej pracy promowany będzie pogląd, iż pod względem swojej trudności nie odbiega on wcale znacząco od programu badania historii życia na Ziemi. W obu przypadkach mamy do czynienia z olbrzymią ilością materiału badawczego - i tak niemożliwego do objęcia przez jednego badacza - oraz z licznymi lukami w naszej wiedzy, a także świadomością, że całkowite wypełnienie tych luk zawsze pozostanie tylko nieosiągalnym ideałem. Dwa nieskończone obszary zakrytych przed nami faktów są równie wielkie wobec naszych skończonych możliwości intelektualnych.

Proponowana tu metoda badań opiera się więc na założeniach podobnych do tych, na jakich opierają się badania innych, wspominanych wyżej procesów historycznych. Przede wszystkim, ponieważ pełna wiedza o badanym procesie jest nieosiągalna, należy ograniczyć się do badania aktualnego stanu wiedzy ludzkiej o tym 
procesie, generując uogólnienia na tej podstawie - jest to po prostu klasyczna metoda indukcji, która, niestety, ma obecnie - zupełnie niezasłużenie - bardzo słabą markę jako metoda analizy filozoficznej.

Przedmiotem badań ma być więc całokształt znanych ludzkości form i procesów naturalnych. Samodzielna systematyczna analiza tego materiału nie jest zadaniem trywialnym, pożądane jest więc skorzystanie $\mathrm{z}$ istniejących systematyzacji tegoż materiału. Na szczęście, istnieją wyczerpujące spisy zagadnień naukowych, tworzone dla potrzeb bibliotekoznawstwa i naukoznawstwa.

Jedną z możliwości jest wykorzystanie któregoś z międzynarodowych systemów klasyfikacji bibliotecznej, np. system Deweya (Dewey Decimal Classification) albo Universal Decimal Classification. Dla potrzeb niniejszej pracy zanalizowano system klasyfikacji artykułów naukowych PACS ${ }^{\circledR}$ 2008: Physics and Astronomy Classification Scheme 2008 opublikowany przez American Institute of Physics $^{11}$. Jest to 5-poziomowy hierarchiczny system klasyfikacji treści naukowych obejmujący przede wszystkich zagadnienia z zakresu fizyki i astronomii, ale także chemii, nauk o Ziemi, biologii, materiałoznawstwa i in. Hierarchiczna struktura PACS umożliwia dowolnie szczegółową analizę; tutaj wybrano do badania poziom 3 hierarchii, obejmujący ok. 400 kategorii, np. „23.60. Rozpad alfa”, „44.25. Konwekcja naturalna”, „52.35. Fale, oscylacje i niestabilności z plazmie”, „82.50. Fotochemia”, „45.70. Materiały granularne”, „96.15. Planety gazowe”, ,91.40. Wulkanologia” itp. Po wstępnej redukcji danych, polegającej na usunięciu z listy zagadnień związanych wyłącznie z działalnością człowieka (np. „42.55. Lasery”, „93.85. Instrumenty i techniki badań geofizycznych” czy „84.30. Obwody elektroniczne"), pozostało 349 kategorii tematycznych.

Istnieją oczywiste problemy z tak uzyskaną listą kategorii. Po pierwsze, nie ma gwarancji, że jest ona wyczerpująca. Po drugie, jest ona z pewnością, „fizyko-centryczna”. To dwa poważne proble-

\footnotetext{
11 Physics and Astronomy Classification Scheme ${ }^{\circledR} \quad 2008$, $<$ http://www.global-sci.org/jams/authors/pacs2008.pdf> , 27.03.2011.
} 
my, jednak ze względów praktycznych są one nie do uniknięcia. Nikt dotychczas nie podjął się jeszcze skonstruowania wyważonej listy wszystkich przedmiotów i procesów naturalnych znanych ludzkości, a istniejace listy zawsze mają spełniać przede wszystkim cele praktyczne. Przykładowo, katalogi biblioteczne nie są fizykocentryczne, jednak są znacznie mniej szczegółowe i tym samym mniej wyczerpujące. Jedną z możliwości na przyszłą kontynuację tego programu badawczego jest zintegrowanie PACS z analogicznymi systemami klasyfikacyjnymi stosowanymi w innych naukach - program ten na pewno warto będzie rozwijać w przyszłości. Na obecnym etapie badań warto pamiętać przede wszystkim, że uzyskana lista uwypukla „nie-biologiczną” część Wszechświata (tylko 16 spośród 349 kategorii dotyczy przedmiotów i zjawisk ściśle biologicznych).

Po trzecie, warto zauważyć, że system PACS powstał, by dopomóc w klasyfikacji artykułów naukowych, a nie zjawisk naturalnych - jego treść należy więc pierwotnie interpretować naukoznawczo, a nie przyrodniczo. Założeniem tej pracy jest więc pewnego typu odpowiedniość między strukturą nauki a strukturą świata; w praktyce okazuje się jednak, że nie jest to założenie tak wątpliwe, jak mogłoby się to wydawać z czysto epistemologicznego punktu widzenia. Większość kategorii PACS składa się z nazw typu: „fotoemisja z ciała stałego”, „gwiazdy podwójne” albo „wzrost kryształów", które można równie łatwo interpretować przyrodniczo, co naukoznawczo. W innych przypadkach z obecnej w PACS nazwy można w prosty sposób utworzyć nazwę przedmiotu lub procesu fizycznego, np. z kategorii „34.10. Ogólne teorie i modele zderzeń i oddziaływań atomowych i molekularnych", która w oczywisty sposób dotyczy „zderzeń i oddziaływań atomowych i molekularnych”. Ogólnie, waga tego problemu wydaje się być znacznie mniejsza od wagi problemów opisanych wcześniej.

Uzyskaną w opisany sposób listę kategorii naniesiono na schemat historycznego rozwoju Wszechświata (rys. 1). W zarysie sche- 
mat ten zawiera ${ }^{12}$ : Wielki Wybuch i jego podstawowe fazy, następnie epokę rekombinacji i formowania się struktur wielkoskalowych, galaktyk i innych układów gwiezdnych (gromady kuliste, gromady otwarte itp.), powstawanie gwiazd i ich późniejszą ewolucję wraz z nukleosyntezą, późne etapy ewolucji gwiazd (etap czerwonego olbrzyma i gałęzi asymptotycznej, wybuch supernowej itp.) i skondensowane pozostałości tej ewolucji (białe karły, czarne dziury itp.), a także późniejszą ewolucję gazu gwiezdnego - rekombinację, powstawanie związków chemicznych, minerałów i ziaren; następnie, obok powstawania gwiazd, również powstawanie układów planetarnych, wzrost ciał stałych w dysku protoplanetarnym i późniejszą ewolucję komet, planetoid i planet, a w szczególności rozwój powierzchni planet skalistych: geologię strukturalną i tektonikę, geomorfologię i geochemię, także rozwój materiałów i układów chemicznych, a ostatecznie rozwój życia i jego ewolucję.

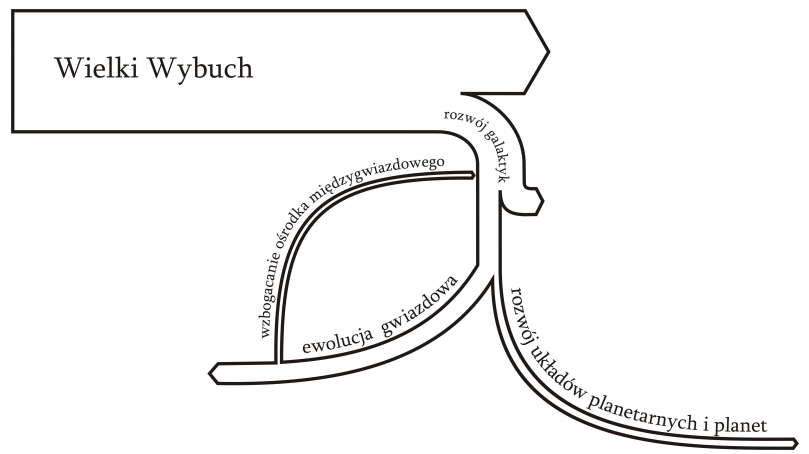

Rys. 1. Uzyskany w badaniu schemat historii Wszechświata.

12 Niektóre ważniejsze źródła: M. Jaroszyński, Galaktyki i budowa Wszechświata, PWN, Warszawa 1993; A.M. Shaw, Astrochemistry, John Wiley \& Sons Ltd, Chichester 2006; B. Pagel, Nucleosynthesis and Chemical Evolution of Galaxies, Cambridge University Press, Cambridge 1997; P. Artymowicz, Astrofizyka układów planetarnych, PWN, Warszawa 1995; Planets and Moons, T. Spohn (ed.), Elsevier, Amsterdam i in. 2007; R.M. Hazen i in., ,Mineral evolution", American Mineralogist 93 (2008), 1693-1720 ; R. Dadlez, W. Jaroszewski, Tektonika, PWN, Warszawa 1994. 
Każda kategoria PACS została następnie umieszczona w miejscu, w którym odpowiadający jej przedmiot lub proces fizyczny zaistniały po raz pierwszy. Przykładowo, kategoria „79.60. Fotoemisja z powierzchni materii skondensowanej" została umieszczona w punkcie, w którym pojawiły się pierwsze ciała stałe, czyli w punkcie odpowiadającym zewnętrznym otoczkom gwiazd z późnym etapie ich ewolucji, zaś kategoria „97.80. Gwiazdy podwójne i wielokrotne" w punkcie reprezentującym powstawanie gwiazd z materii gazowej galaktyk. Dzięki temu rozważane były wyłącznie „,nowości ontologiczne”, tj. sytuacje, w których obiekt reprezentowany przez daną kategorię pojawił się po raz pierwszy, zaś nie są odnotowane wszystkie późniejsze przypadki występowania tego obiektu.

Przykładowo, raz powstałe ciało stałe może emitować ze swojej powierzchni fotony dowolnie długo, a więc - mówiąc już w kategoriach naszego wykresu - również $\mathrm{w}$ fazie ewolucji w ośrodku międzygwiazdowym, w dysku protoplanetarnym itd., dopóki nie zostanie zniszczone lub zamknięte we wnętrzu innego ciała stałego. Odpowiadająca temu procesowi fizycznemu kategoria umieszczona jest jednak na wykresie wyłącznie raz. Metoda ta odpowiada celowi badania, którym było odnalezienie tych „obszarów” historii świata, w których zaszedł największy zlokalizowany wzrost jego złożoności, nie zaś śledzenie całkowitej złożoności świata. Jak więc widać, złożoność danego układu parametryzowana jest przez ilość występujących w jego ramach obiektów fizycznych, zaś wzrost złożoności na danym etapie rozwoju świata przez ilość zjawisk występujących na tym etapie po raz pierwszy.

Co ciekawe, schemat historii Wszechświata stanowiący „tło" analizy był po części założony wstępnie, po części zaś wyłaniał się spontanicznie $\mathrm{w}$ trakcie pracy nad umieszczaniem na nim kategorii PACS. Ostatecznie otrzymał formę „oszczędną”, to znaczy pozostały na nim wyłącznie te „ścieżki ewolucji”, które zawierają jakiekolwiek kategorie. Zupełnie naturalnie pokazane są więc wyłącznie te obszary historii świata, w których „,coś się dzieje”. Uwzględnienie 
większej ilości kategorii (np. rozszerzenie analizy o 4 poziom systemu PACS) prawdopodobnie spowodowałoby również zwiększenie szczegółowości stosowanego schematu historycznego.

Parę ustaleń terminologicznych. W poniższej dyskusji wyrażenie „obiekt fizyczny” oznaczać będzie przedmiot lub proces fizyczny denotowany przez którąś z kategorii PACS. Określenie „fizyczny" powinno być traktowane tak neutralnie, jak to tylko możliwe; czasem zamiast niego używane jest ze względów stylistycznych słowo „naturalny”. Obydwa można zoperacjonalizować jako dotyczące obiektów obecnych w katalogu PACS, aby zminimalizować ilość założeń filozoficznych. Podobnie, wymiennie używane są określenia „Wszechświat”, ,świat” itp., które można zoperacjonalizować analogicznie. Określenia „przestrzenne” (np. „obszar”, ,miejsce” itp.) odnoszą się do abstrakcyjnej przestrzeni wykresu, na który naniesione zostały kategorie PACS (rys. 1), chyba że wyraźnie zaznaczono, że chodzi o przestrzeń fizyczną.

\section{Rezultaty: wstęp}

Zastanówmy się najpierw, jakiego typu rezultaty mogą być osiągnięte w badaniu przedstawionego typu. Po pierwsze, nie wydaje się, aby opisana metoda mogła sama w sobie przynieść rezultaty par excellence ,filozoficzne”. Zostawiając już na boku wątpliwe założenia tej metody i jej braki - bo kiepski wynik filozoficzny to jednak wciąż wynik filozoficzny - warto zauważyć przede wszystkim, że badanie to nie jest przeprowadzane w ramach żadnej tradycji filozoficznej ani przy użyciu języka którejkolwiek z dyscyplin filozoficznych. Jego celem było po prostu uogólnienie stanu współczesnej wiedzy przyrodniczej nakierowane na jeden określony temat - wzrost ilości „przedmiotów i procesów” w ewoluującym Wszechświecie. Z opisanych rezultatów można dopiero wtórnie wyciągać wnioski filozoficzne - jest to możliwe m.in. w sytuacji, w której dany filozof lub dana tradycja filozoficzna jawnie korzysta z wyników naukowych. 
We wstępie zasugerowane zostały obszary leżące w zakresie współczesnych nauk filozoficznych, które wydają się jawnie korzystać z danych naukowych. Niniejsza praca jest wyrazem przekonania, iż jeśli już korzysta się z dorobku nauki, należy robić to systematycznie. Wybór z całokształtu naszej wiedzy naukowej jednego lub kilku przykładów „na chybił trafił” i analiza na ich przykładzie globalnej własności Wszechświata jest metodologiczną naiwnością. Jedyną racjonalną drogą jest „droga globalna”: jeśli stosować indukcję, to jawnie i z rozmachem, a nie skrycie i po troszku.

Oprócz powyższego zastrzeżenia wydaje się, że opisywana metoda jest na tyle neutralna, że można uzyskane na jej drodze wyniki zastosować do analizy dowolnego problemu leżącego w określonym wyżej zakresie tematycznym. Poniższe rozważania mają ilustrować potencjalny zakres stosowania metody i przybliżyć kilka podstawowych rezultatów osiągniętych na drodze przeprowadzonych analiz.

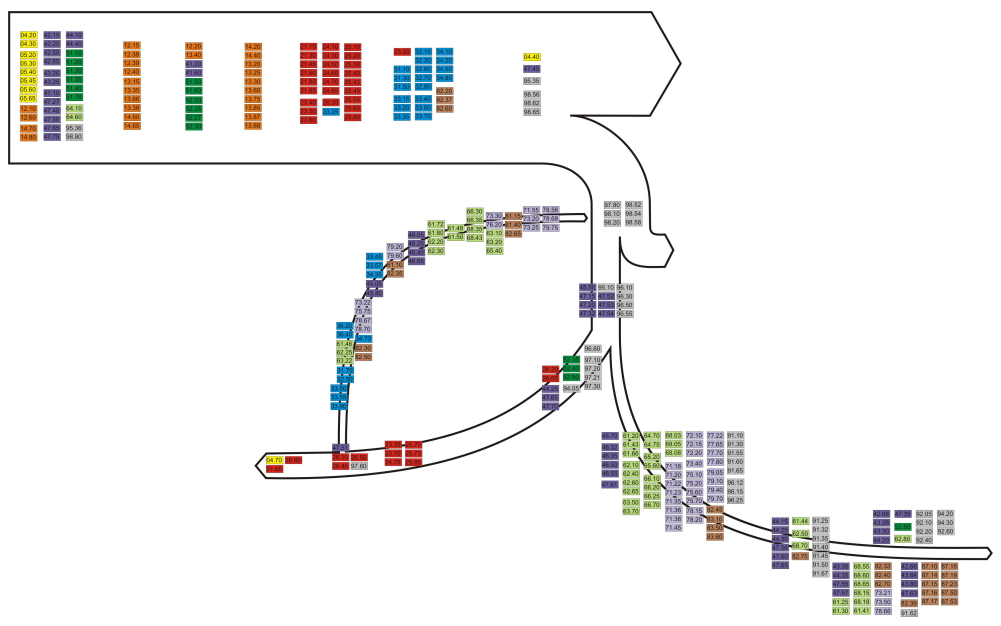

Rys. 2. Uzyskany w badaniu schemat ilustrujacy wzrost złożoności świata w miarę jego historycznego rozwoju. Każdy prostokąt symbolizuje jedną z 349 kategorii PACS analizowanych w badaniu. Kolorem oznaczono przynależność do jednej z 9 głównych grup tematycznych, zgodnie z 1 poziomem hierarchii PACS. 


\section{Czy świat fizyczny zorganizowany jest w dyskretne „poziomy"?}

Przeprowadzone badania pokazują kilka interesujących faktów dotyczących „punktowości” wielkich przemian w rozwoju świata. Przede wszystkim, Wszechświat ewoluuje „nierówno”. Obszar Wielkiego Wybuchu (liczonego łącznie z okresem rekombinacji) zawiera w sumie 114 obiektów w 6 głównych grupach, następujących po sobie sekwencyjnie. Wynika z tego, że ok. 1/3 spośród wszystkich obiektów fizycznych pojawia się w trakcie Wielkiego Wybuchu i jest „dziedziczona” przez cała fizyczną przestrzeń Wszechświata. W przeciwieństwie do tej grupy, pozostałe $2 / 3$ obiektów występuje wyłącznie w zlokalizowanych przestrzennie obszarach - np. 12 obiektów właściwych dla układów planetarnych traktowanych jako całość, 14 obiektów właściwych tylko dla hydrosfer i atmosfer planet skalistych itd. Świat osiagga więc coraz to większą złożoność w sposób zlokalizowany, a nie globalnie, co stawia pod znakiem zapytania wszelkie koncepcje odwołujące się do hierarchicznie następujących po sobie ,poziomów”. Przykładowo, bogactwo zjawisk chemicznych jest ledwie napoczęte w przestrzeni międzygalaktycznej, która nie uczestniczyła w „rewolucji chemicznej” inicjowanej przez nukleosyntezę odbywającą się w masywnych gwiazdach. Jeszcze inna grupa procesów chemicznych zachodzi wyłącznie na powierzchniach ciał stałych w układach planetarnych, gdzie rozwój „poziomu” chemicznego uzależniony jest częściowo od zjawisk astrofizycznych i geologicznych. W tym sensie zamiast o jednej „chemii” powinno się mówić raczej o różnych „chemiach”.

Co ciekawe, mimo zasadniczej ciągłości procesów naturalnych, dają się dostrzec bardzo wyraźne „obszary krytyczne”, ogniskujące w sobie znaczną ilość nowych obiektów. Obok (a) Wielkiego Wybuchu (114 nowych obiektów) są to przede wszystkim trzy obszary:

(b) zewnętrzne warstwy gwiazd w ostatniej fazie ich ewolucji oraz zrzucone otoczki gazowe (54 obiekty);

(c) dyski protoplanetarne (76 obiektów); 
(d) młode planety skaliste (49 obiektów).

W obszarze (b) pojawia się po raz pierwszy przede wszystkim znaczna ilość obiektów chemicznych oraz „suprachemicznych” (tj. polimerów, agregatów związanych słabymi oddziaływaniami międzycząsteczkowymi, nanokryształów itp.). Pojawia się też pewna niewielka ilość obiektów mineralogicznych. W obszarze (c) zachodzi przede wszystkim intensywny wzrost ciał stałych, co pociagga za sobą pojawienie się np. minerałów o właściwościach magnetycznych i przewodzących, zbudowanych z nich skał, ale także pierwszych prawdziwych płynów. w obszarze (d) rozwija się petrologia, geologia strukturalna, geomorfologia, pojawiają się zjawiska atmosferyczne i hydrosferyczne oraz rozwija się na szeroką skalę tzw. soft matter, czyli piany, koloidy, emulsje, membrany, micele itp.

Po zsumowaniu tak wydzielonych 4 obszarów zlokalizowanego wzrostu złożoności naturalnej otrzymujemy łącznie 293 obiekty, czyli $84 \%$ wszystkich obiektów wydzielonych dla celów analizy. Pozostałych $16 \%$ obiektów grupuje się w 7 pomniejszych grupkach, z których największa - odpowiadająca ewolucji gwiazd na ciągu głównym - zawiera jedynie 14 obiektów. Podobnej wielkości jest grupa obiektów odpowiadająca życiu na Ziemi, jednak ze względu na ograniczenia opisane wyżej nie należy ona do głównego zakresu tematycznego analizy.

Widzimy więc, że wzrost złożoności świata zdominowany jest przez zlokalizowane epizody. Co istotne, wszystkie te 4 epizody są zjawiskami krótkotrwałymi w skali kosmicznej (rys. 3), także w porównaniu z ,sąsiadującymi" procesami naturalnymi:

(A) Wszystkie 114 obiektów leżących w obszarze Wielkiego Wybuchu pojawia się w ciągu ok. 106 lat. Następujący później etap etap formowania się wielkoskalowych struktur kosmicznych - rozciąga się w skali 109-1010 lat i trwa do dziś, zaś odpowiadający mu obszar analizowanego tu schematu zawiera zaledwie 6 obiektów.

(B) Ostatnia faza ewolucji gwiazd trwa ok. 106-107 lat, podczas gdy wcześniejsza statyczna ewolucja na ciągu głównym trwa typowo od 108-1010 lat, zaś późniejsza ewolucja materiału gazo- 
wego i pyłowego powstałego w tej krótkiej fazie zachodzi w skali 108-109 lat.

(C) Dyski protoplanetarne formuja się w ciagu 107 lat i po podobnym okresie są niszczone - późniejsza ewolucja układów planetarnych trwa zaś 109-1010 lat.

(D) Planety skaliste już po 107-108 lat ustalają większość swoich parametrów geofizycznych, tektonicznych i geochemicznych - późniejsza ich ewolucja może natomiast trwać od 109 lat, praktycznie dowolnie długo i przebiegać bez żadnych znaczacych globalnych przemian.
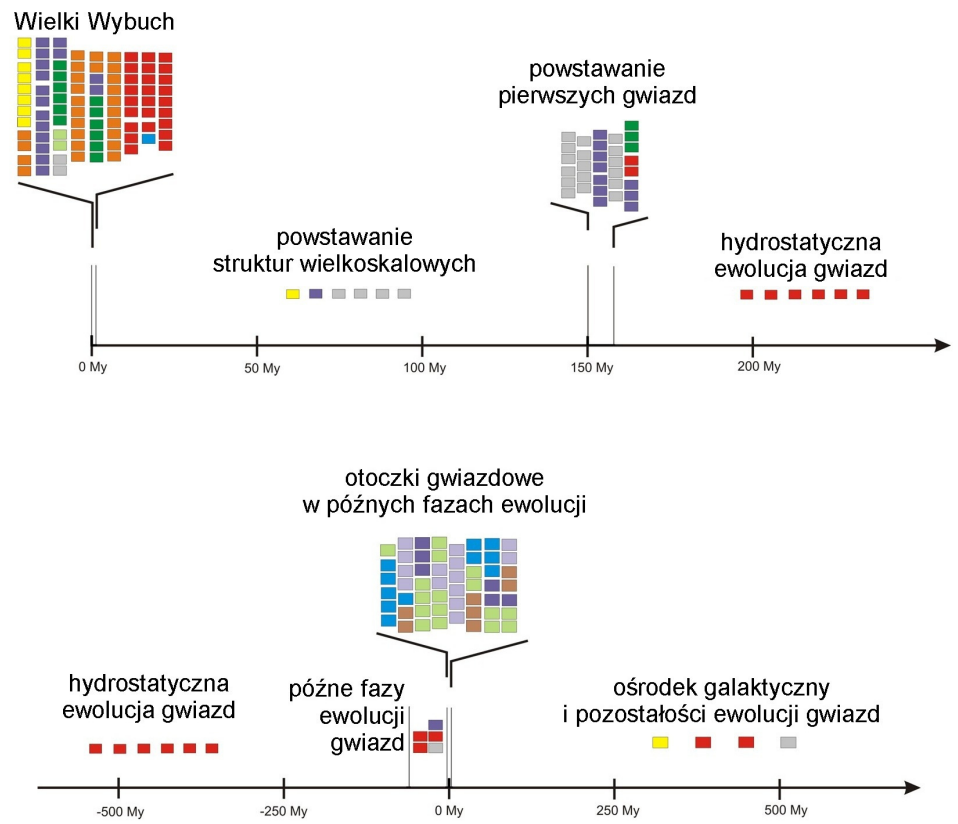

Rys. 3. Wybrane epizody intensywnego wzrostu złożoności świata naniesione na skalę czasową ( $\mathrm{My}=$ milion lat).

Podsumowując, w ciągłym procesie przemian naturalnych faktycznie da się wyróżnić stosunkowo wyraźne (zlokalizowane i krótkotrwałe) oraz intensywne (skupiające na sobie powstanie, kolej- 
no, $33 \%, 15 \%, 22 \%$ i $14 \%$ wszystkich obiektów fizycznych) epizody skoncentrowanych przemian reprezentujące znaczący wzrost złożoności świata fizycznego. Żaden z tych epizodów nie odpowiada jednak tradycyjnie wyróżnianym „poziomom” organizacji świata (np. poziomowi ,fizycznemu”, ,chemicznemu” czy „organicznemu”). Gdyby rzeczywiście chcieć podzielić historię ewolucyjną Wszechświata na dyskretne „fazy” o w miarę ustalonej strukturze przedzielone epizodami intensywnego wzrostu złożoności, byłyby to raczej etapy:

1. przed-jadrowej mieszaniny wygenerowanej w Wielkim Wybuchu, zawierającej tylko najprostsze jądra (głównie $\mathrm{H}$ i He), organizującej się wyłącznie w struktury w skali galaktycznej i ponad-galaktycznej;

2. post-jadrowej mieszaniny wygenerowanej $\mathrm{w}$ gwiazdach, zawierającej wszystkie znane nam obecnie jądra i organizującej się w struktury w skali gwiazdowej oraz mikroskopowej (proste związki chemiczne, ziarna i agregaty o rozmiarach liniowych $<1 \mu \mathrm{m})$;

3. protoplanetarnej mieszaniny (która przeszła już przynajmniej jeden cykl wzbogacania „post-jądrowego”), składającej się z ciał stałych i półstałych o rozmiarach makroskopowych (rozmiary liniowe: $1 \mu \mathrm{m}-1 \mathrm{~km}$ ), wykazujacych większość znanych nam zjawisk fizycznych właściwych dla ciał stałych i płynów, a także pewną ilość zjawisk chemicznych i geologicznych;

4. fazy planetarnej, w której istotne stają się efekty grawitacji: na powierzchni gromadzi się atmosfera i hydrosfera, a także wzrasta bogactwo minerałów, skał, układów chemicznych i soft matter; ostatecznie może się także tworzyć życie typu ziemskiego. 
Faza (1) jest globalna. Fazy (2), (3) i (4) ograniczone są przestrzennie do obszaru układów galaktycznych. Fazy (3) i (4) ograniczone są jeszcze bardziej: do obszaru układów planetarnych.

\section{Uwagi na temat pojęcia ,fundamentalności”}

Warto zwrócić w tym momencie uwagę na znaczący fakt terminologiczny. Wydzielenie w strukturze świata pewnych „poziomów organizacji" jest zasadniczo ahistoryczne i konotuje statyczną, logicznie uorganizowaną strukturą rzeczywistości fizycznej, w której „wyższe” typy organizacji wyłaniają się z „niższych” na sposób podobny do tego, w jaki wyłaniają się nawzajem z siebie nauki w myśl modelu teoretyczno-redukcyjnego ${ }^{13}$. Zauważmy, że w dyskusji na temat „emergencji” bardzo często stosuje się język odwołujący się do takiej właśnie wizji rzeczywistości: istnienia pewnych uporządkowanych pod względem ,fundamentalności" poziomów, z których wyższy domaga się wyjaśnienia w kategoriach poziomu niższego. Taką właśnie wizję ontologii przedstawiał N. Hartmann ${ }^{14}$. Taka jest też wizja, która przewija się w dyskusjach nad „teorią wszystkiego" - hipotetyczną teorią fizyczną unifikującą teorię fundamentalnych oddziaływań mikroskopowych z ogólną teorią względności.

Przeciwstawiany tu model jest zasadniczo historyczny, więc zamiast „poziomów” mówi się raczej o horyzontalnej ciągłości przemian, podzielonej ewentualnie w „etapy" według jakiejś, bardziej czy mniej arbitralnej, metody. Ponadto, trudno jest tu mówić o poziomie bardziej lub mniej fundamentalnym, tym bardziej w powiązaniu z dominującym obecnie hierarchicznym modelem struktury nauki. Faktycznie, istnieje pewna ilość obiektów fizycznych „pierwotnych" (jest ich 36), występujących w jednej, wydzielonej grupie, wcześniejszej od wszystkich pozostałych, którą można by nazwać „pakietem startowym”. Skład tej grupy nie odpowiada jednak powszechnym wyobrażeniom o fundamentalności, kreowanym przez

${ }^{13}$ Zob. np. J. Werle, Jedność przyrody - rzeczywistość czy iluzja, Wszechnica Polskiej Akademii Nauk, Wrocław 1992, s. 32.

${ }^{14}$ N. Hartmann: dz.cyt. 
dyskusje o tzw. „fizyce fundamentalnej”, zawierającej zwykle fizykę cząstek elementarnych oraz kosmologię fizyczną ufundowaną na teorii względności. Po pierwsze, w „pakiecie startowym” występuje tylko część tzw. „fizyki fundamentalnej”, zaś inne jej elementy pojawiają się znacznie później, np. czarne dziury, których powstawanie poprzedzone jest - i przyczynowo uwarunkowane - przez etap ewolucji gwiazd. Po drugie, występują w nim również obiekty związane z mechaniką płynów, fizyką plazmy czy termodynamiką fenomenologiczną - nijak nie leżące w zakresie tzw. ,fizyki fundamentalnej".

Zauważmy też, że tradycyjne rozumienie „poziomów złożoności" związane jest organicznie ze schematem redukcji teoretycznej nauk: stąd np. owo często cytowane następstwo fizyka-chemiabiologia-psychologia. Omawiana tu analiza pokazuje wprost, że o ile w największym przybliżeniu kolejność ta jest spełniona (w tym sensie, że nie było żadnej biologii przed jakąkolwiek chemią itd.), to w szczegółach obraz jest znacznie bardziej subtelny. Istnieja obiekty opisywane tradycyjnie przez fizykę domagające się wcześniejszego rozwoju obiektów chemicznych - np. ciekłe kryształy, które mogą występować wyłącznie na bazie materiałów o znacznej złożoności (np. lipidów albo innych związków organicznych podobnych rozmiarów), przez co wymagają do swojego zaistnienia długiego etapu wcześniejszej ewolucji chemicznej. Ba, istnieją obiekty fizyczne, które mają miejsce wyłącznie w świecie biologicznym - np. soczewki o zmiennej ogniskowej i związane z tym zjawiska optyczne.

Zauważmy na marginesie, że wykluczone przeze mnie na samym początku analizy zagadnienia ,związane wyłącznie z działalnością człowieka" należą właśnie do szczególnej podgrupy tej podgrupy. Wedle naszej wiedzy, nadprzewodnictwo albo „ciecze kwantowe” (np. nadciekły hel-3) nie występują poza ludzkimi laboratoriami. (Choć nie jest to absolutnie wykluczone, warto zwrócić uwagę choćby na to, że w obecnej epoce kosmologicznej schłodzenie jakiegokolwiek obiektu poniżej temperatury 2,7 kelwina sprawia, że 
schłodzony obiekt znajduje się w stanie nierównowagi termodynamicznej z kosmicznym promieniowaniem tła, więc jego utrzymywanie poniżej tej temperatury wymaga stałego nakładu pracy. Ponadto, w przyrodzie z zasady nie występują substancje ultraczyste.) Wygląda więc na to, że za sprawą przyczyn psychologicznych doszło do „realizacji” - kto wie, czy nie po raz pierwszy we Wszechświecie - bardzo fundamentalnych zjawisk kwantowych. Naturalnym domknięciem tych rozważań są koncepcje futurologów i zwolenników transhumanizmu, zgodnie z którymi nie ma w zasadzie granic dla ludzkich możliwości stwórczych, w związku z czym niewykluczone, że będziemy niegdyś jako cywilizacja rutynowo powoływać do życia całe nowe wszechświaty. Dalej poza schemat redukcjonistyczny wyjść już się chyba nie da.

\section{Podsumowanie i perspektywa dalszych badań}

Przedstawiona w niniejszej pracy metoda umożliwia ilościowy opis procesu wzrostu złożoności świata w toku kosmicznej ewolucji, poprzez analizę listy „obiektów fizycznych” (rozumianych tu jako przedmioty i procesy fizyczne), mających reprezentować wszystkie składniki świata fizycznego znane obecnie ludzkości. „Ilościowość" ta jest oczywiście czysto symboliczna, ponieważ konstrukcja takiej listy nie jest zadaniem trywialnym i nie daje się w żaden sposób „zautomatyzować”. W chwili obecnej używana dla celów analizy lista zawiera raczej (wszystkie?) „obiekty zainteresowania fizyków i niektórych innych naukowców stosujących metody fizyki" niż (wszystkie?) „obiekty fizyczne”. Na ile jedna grupa ma się do drugiej - pozostaje sprawą otwartą. W przyszłości należałoby przede wszystkim zadbać o sprawiedliwy (tylko co to właściwie znaczy?) udział wszystkich dyscyplin nauk przyrodniczych.

Istnieją oczywiste problemy metodologiczne i filozoficzne związanych z opisanym tu programem badawczym. Część z nich zostało już omówionych wcześniej; niektóre z pozostałych warto choćby wymienić. Jak podzielić ciągłe bogactwo zjawisk naturalnych na dyskretne „obiekty”? Jak w ogóle wyróżnić „obiekt”? Jak silną „wa- 
gę" należy przykładać do poszczególnych obszarów tematycznych? Przykładowo, związki chemiczne można dzielić na nieorganiczne i organiczne; te drugie np. na aromatyczne i alifatyczne; z drugiej strony organizmy żywe dzieli się na prokariotyczne i eukariotyczne; te drugie na protozoa, grzyby, rośliny i zwierzęta. Jak porównywać ,wagę" tego typu kompletnie nieprzywiedlnych systemów klasyfikacji? Czy „odkrycie” przez Naturę pierścienia benzenowego można porównywać względem poziomu „nowatorstwa” do ewolucji organizmów eukariotycznych czy też raczej do powstania zwierząt? Pytania te mogą wydawać się absurdalnie trudne, wręcz na granicy bezsensowności; wydaje się jednak, że samo poszukiwanie na nie odpowiedzi może przynieść znaczące pogłębienie rozważań na temat „emergencji” i zjawisk „emergencjo-podobnych”. Dopóki nie zostaną one rozważone, nie ma żadnego racjonalnego powodu, dla którego powstanie życia miałoby być uważane za przejaw jakkolwiek rozumianej ,emergencji”, a powstanie pierwszej cząsteczki benzenu z cząstek dotychczas liniowych - nie. Jeśli zaś wszystko jest „emergencją", nic tak naprawdę na to miano nie zasługuje.

Obok tych kwestii występują naturalnie problemy czysto merytoryczne, na omówienie których nie ma tu miejsca. W wielu przypadkach przypisanie określonego obiektu do danego miejsca było w mniejszym czy większym stopniu arbitralne, prawie zawsze zaś - trudne. Istnieją też oczywiście „obiektywne” obszary niewiedzy, np. związane z ewolucją chemiczną otoczek gwiazdowych albo mineralogią dysków protoplanetarnych, która znana jest obecnie tylko w zarysie. Istnieje też więcej niż jeden sposób na uporządkowanie używanego schematu, choć zakładana w niniejszej pracy wizja historii Wszechświata jest już dosyć dobrze potwierdzona.

Biorąc jednak pod uwagę wszystkie powyższe zastrzeżenia, mimo wszystko wydaje się, że opisany program badawczy warto kontynuować. Potencjalne rezultaty poznawcze są niebagatelne, a opisane wyżej prawidłowości są dopiero prawidłowościami. Od prawidłowości do teorii - o której mowa w tytule - długa droga. 


\section{Bibliografia}

1. S. Alexander, Space, Time and Deity. The Gifford Lectures at Glasgow 1916-1918, Macmillan and Co., Londyn 1927.

2. P. Artymowicz, Astrofizyka układów planetarnych, PWN, Warszawa 1995.

3. J. Cat, „Unity and Disunity of Science”, [w:] S. Sarkar, J. Pfeifer, The Philosophy of Science. An Encyclopedia, Routledge, Nowy Jork - Londyn 2006, s. 842-847.

4. N. Hartmann, Nowe drogi ontologii, przeł. L. Kopciuch i A. Mordka, Rolewski, Toruń 1998.

5. R.M. Hazen i in., „Mineral evolution”, American Mineralogist 93 (2008), 1693-1720.

6. M. Kaku, Wszechświaty równoległe, Prószyński i S-ka, Warszawa 2006.

7. S. Kauffman, Origins of Order, Oxford University Press, Oxford 1993.

8. M. Jaroszyński, Galaktyki i budowa Wszechświata, PWN, Warszawa 1993.

9. L. Morgan, Emergent Evolution, Williams \& Norgate, Londyn 1923.

10. E. Nagel, Struktura nauki, PWN, Warszawa 1970.

11. PACS: Physics and Astronomy Classification Scheme 2008, 27.03.2011, $<$ www.global-sci.org/jams/authors/pacs2008.pdf >.

12. B. Pagel, Nucleosynthesis and Chemical Evolution of Galaxies, Cambridge University Press, Cambridge 1997. 
13. I. Prigogine, Thermodynamics of Irreversible Processes, Wiley, New York 1961.

14. A.M. Shaw, Astrochemistry, John Wiley \& Sons Ltd, Chichester 2006.

15. Planets and Moons, T. Spohn (ed.), Elsevier, Amsterdam i in. 2007.

16. J. Werle, Jedność przyrody - rzeczywistość czy iluzja, Wszechnica Polskiej Akademii Nauk, Wrocław 1992.

17. W.C. Wimsatt, S. Sarkar, „Reductionism”, [w:] S. Sarkar, J. Pfeifer, The Philosophy of Science. An Encyclopedia, Routledge, Nowy Jork - Londyn 2006, s. 696-702.

18. S. Wolfram, A New Kind of Science, Wolfram Media, Champaign IL 2002.

\section{Abstract}

\section{Towards a quantitative theory of the growth of natural complexity}

The study of the growing complexity of the physical world is of great value to many scientific disciplines, including philosophy of nature, complexity theory, thermodynamics, and others. Here, I propose a systematic and quantitative method of describing the process of natural complexification throughout cosmic history, based on a list of the topical categories of PACS ${ }^{\circledR}$ 2008: Physics and Astronomy Classification Scheme 2008, published by the American Institute of Physics. I assume that each of the selected 349 level-3 categories corresponds to a certain subset of natural phenomena, and I group them according to their first appearance in natural history. By analyzing their distribution, I derive certain qualitative and (tentatively) quantitative generalizations concerning the pace and scale of the growth of natural complexity. I contrast this approach with the results achieved by other methods and discuss 
its relevance to selected topics in philosophy of nature and philosophy of science.

Keywords: complexity: quantitative measures of; emergence; philosophy of nature; philosophy of science 